\title{
ANALISA KEGAGALAN STRUKTUR DAN RETROFITTING BANGUNAN MASJID RAYA ANDALAS PADANG PASCA GEMPA 30 SEPTEMBER 2009
}

\author{
Fauzan $^{1}$
}

\begin{abstract}
ABSTRAK
Gempa tektonik tanggal 30 September 2009 telah banyak menimbulkan kerusakan konstruksi bangunan (engineered building). Kerusakan itu terjadi akibat kegagalan pada struktur dan nonstruktur bangunan. Biasanya setelah gempa bumi terjadi, timbul keraguan untuk menentukan bagian bangunan yang harus dirombak, diperbaiki, diperkuat dan bagaimana cara melakukannya. Penelitian ini bertujuan untuk melakukan analisa penyebab kegagalan struktur pada salah satu bangunan umum di kota Padang yaitu Masjid Raya Andalas Padang. Analisa ini berdasarkan pada kapasitas lentur dan geser struktur dalam menahan gaya luar terutama beban lateral (gempa). Penelitian ini dilakukan melalui evaluasi kerusakan struktur eksisting bangunan, kemudian dilakukan permodelan dan analisa struktur menggunakan software Etabs V 9.0.7 dan SAP V .11. Berdasarkan hasil analisa struktur, sebagian besar kolom-kolom eksisting mempunyai kapasitas penampang yang tidak mampu menahan beban luar. Hasil analisa struktur itu sesuai dengan hasil evaluasi kerusakan dilapangan dimana sebagian besar kolom-kolom mengalami kerusakan baik lentur maupun geser. Agar gedung ini bisa dipergunakan kembali, maka perlu dilakukan perkuatan (retrofitting) pada struktur kolom dengan menggunakan metoda jacketing. Setelah dilakukan perkuatan struktur kemudian dilakukan re-analisis struktur. Berdasarkan hasil reanalisis struktur didapatkan bahwa, beban-beban luar yang bekerja pada struktur kolom sudah berada didalam kapasitas penampang kolom, sehingga disimpulkan struktur bangunan layak kembali untuk digunakan.
\end{abstract}

Kata Kunci : perkuatan, geser, lentur, jacketing

\section{PENDAHULUAN}

Indonesia menempati zona tektonik yang sangat aktif karena tiga lempeng besar dunia dan sembilan lempeng kecil lainnya saling bertemu di wilayah Indonesia dan membentuk jalur-jalur pertemuan lempeng yang kompleks. Keberadaan interaksi antar lempeng-lempeng ini menempatkan wilayah Indonesia sebagai wilayah yang sangat rawan terhadap gempa bumi. Gempa Tektonik pada tanggal 30 September 2009 di Padang dan Pariaman Sumatera Barat telah banyak menimbulkan kerusakan pada konstruksi bangunan (engineered building), baik perumahan rakyat, fasilitas umum, bangunan Pemerintah dan Swasta. Salah satu bangunan di Kota Padang yang mengalami kerusakan akibat gempa tersebut adalah Bangunan Masjid raya Andalas Padang yang terletak di Jl. Andalas Padang dimana kerusakan pada bangunan ini terjadi pada struktur kolom bangunan. Tujuan penelitian ini adalah untuk mengetahui penyebab kegagalan elemen struktur bangunan, sehingga berdasarkan analisa tersebut dapat dilakukan perencanaan dan pelaksanaan retrofitting pada elemen struktur bangunan Masjid Raya Andalas Padang.

Bangunan Masjid Raya Andalas Padang (Gambar 1.) adalah bangunan beton bertulang dua lantai dengan luas $377 \mathrm{~m}^{2}$. Struktur bangunan ini terdiri dari pondasi sumuran, sloof, balok, kolom, pelat lantai dan kubah. Dari hasil penelitian diketahui data spesifikasi teknis bangunan Masjid Raya Andalas sebagai berikut:

\footnotetext{
${ }^{1}$ Dosen Jurusan Teknik Sipil Fakultas Teknik Universitas Andalas, e-mail: fauzan@ft.unand.ac.id
} 


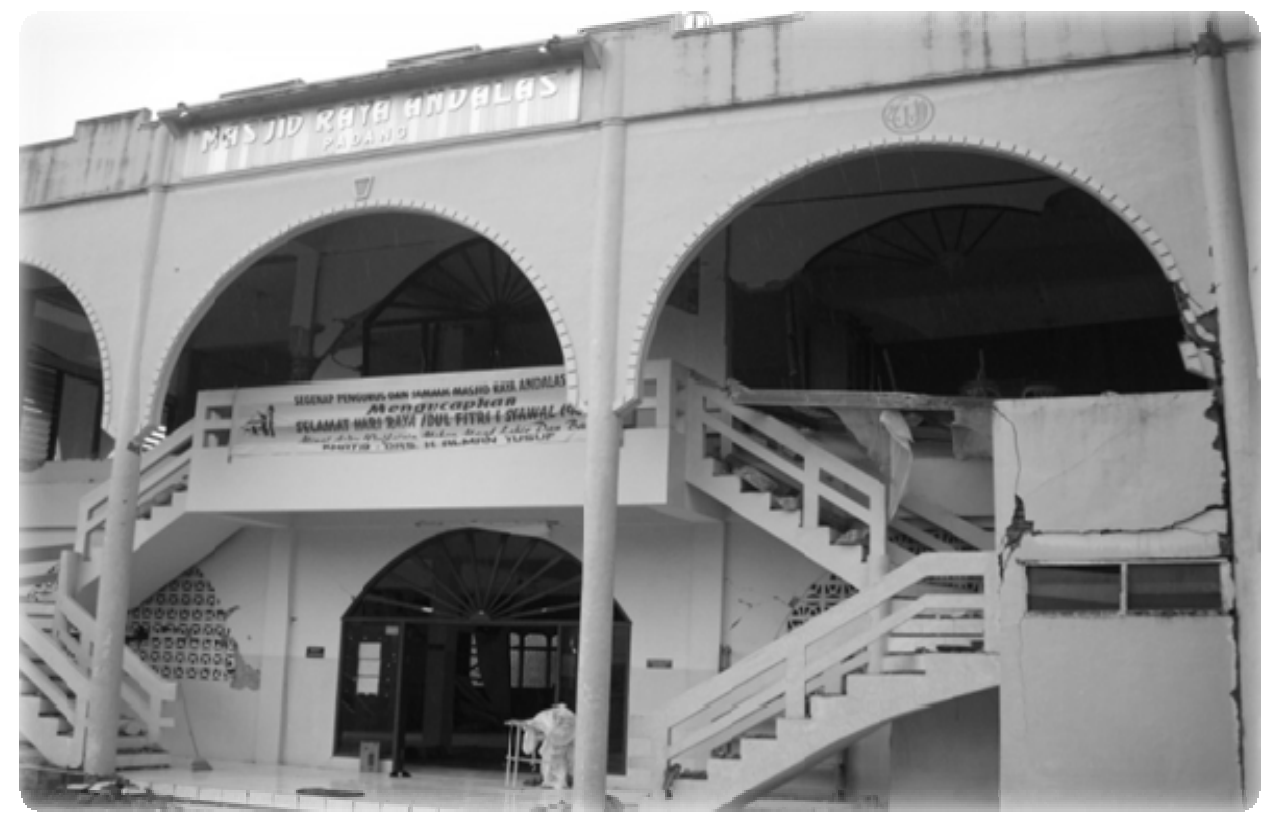

Gambar 1. Tampak Depan Bangunan Masjid Raya Andalas Padang Pasca Gempa

-Dimensi Struktur

-Fungsi Bangunan

-Perencanaan Beton Bertulang

- Mutu Beton struktur Kolom

- Mutu beton struktur Balok

-Mutu Baja Struktur Kolom

- Tebal pelat lantai

- Tebal pelat kubah
: Hasil Pengukuran di Lapangan

: Tempat Ibadah

: SNI 03-2847 2002

: K- 146,8 (Pengujian dengan Hammer Test)

: K- 113,08(Pengujian dengan Hammer Test)

: Mutu besi ulir fy $=4000 \mathrm{~kg} / \mathrm{cm}^{2}$, mutu besi polos $=2400$ $\mathrm{kg} / \mathrm{cm}^{2}$ (Pengujian Uji Tarik Baja)

$: 12 \mathrm{~cm}$

$: 15 \mathrm{~cm}$

\section{EVALUASI STRUKTUR BANGUNAN}

\subsection{Kondisi Eksisting Bangunan}

Bangunan Masjid Raya Andalas memiliki 63 buah kolom yang terdiri dari 41 kolom lantai 1 dan 22 kolom lantai 2, dengan dimensi seperti terlihat pada Tabel 1.

Tabel 1. Dimensi Kolom Terpasang

\begin{tabular}{|c|c|c|c|c|c|}
\hline \multirow{2}{*}{$\begin{array}{c}\text { Tipe } \\
\text { Kolom }\end{array}$} & $\mathrm{b}$ & $\mathrm{H}$ & \multicolumn{3}{|c|}{ Tul. Lentur } \\
\cline { 2 - 6 } & $(\mathrm{mm})$ & $(\mathrm{mm})$ & $\mathrm{n}$ & $\mathrm{D}(\mathrm{mm})$ & $\mathrm{A}\left(\mathrm{mm}^{2}\right)$ \\
\hline K1.30.30 & 300 & 300 & 8 & 16 & 200.96 \\
\hline K2.D30 & 368 & 240 & 8 & 16 & 200.96 \\
\hline K3.D50 & 220 & 400 & 8 & 16 & 200.96 \\
\hline
\end{tabular}




\subsection{Tipe Kerusakan Struktur Kolom}

\subsubsection{Retak Lentur}

Retak lentur memiliki pola dan bentuk retakan secara mendatar dan horizontal yang disebabkan oleh adanya tekanan dari samping kolom yang melebihi kapasitas yang telah diperhitungkan. Pada Gambar 2. terlihat kegagalan struktur kolom akibat lentur pada bangunan Masjid Raya Andalas Padang pasca gempa 30 september 2009.

\subsubsection{Retak Geser}

Retak geser memiliki pola dan bentuk retakan secara diagonal yang disebabkan oleh adanya tekanan dari samping kolom yang melebihi kapasitas yang telah diperhitungkan. Pada Gambar 3. terlihat kegagalan struktur kolom akibat geser pada bangunan Masjid Raya Andalas Padang
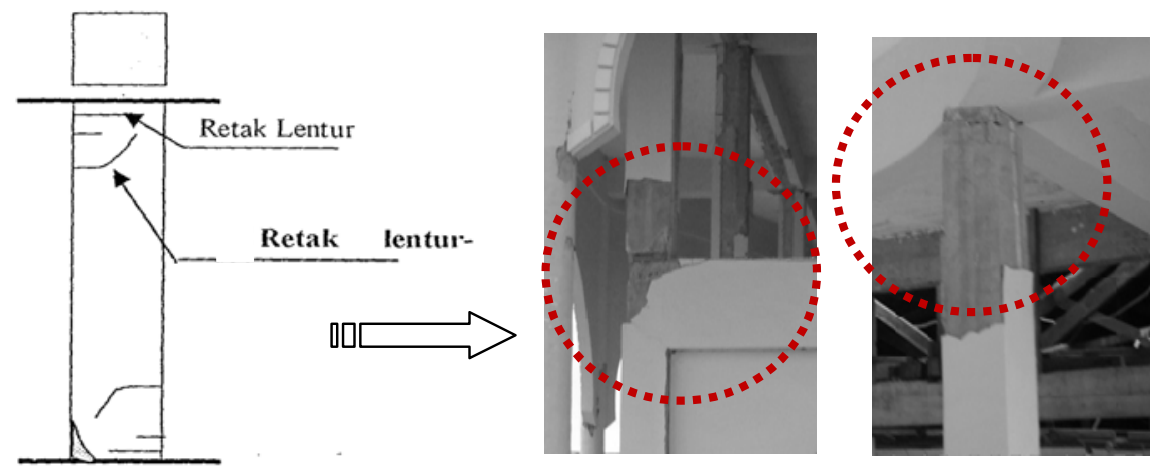

\section{Gambar 2. Bentuk/Pola Retak yang Terjadi Pada Kolom Akibat Beban Lentur}
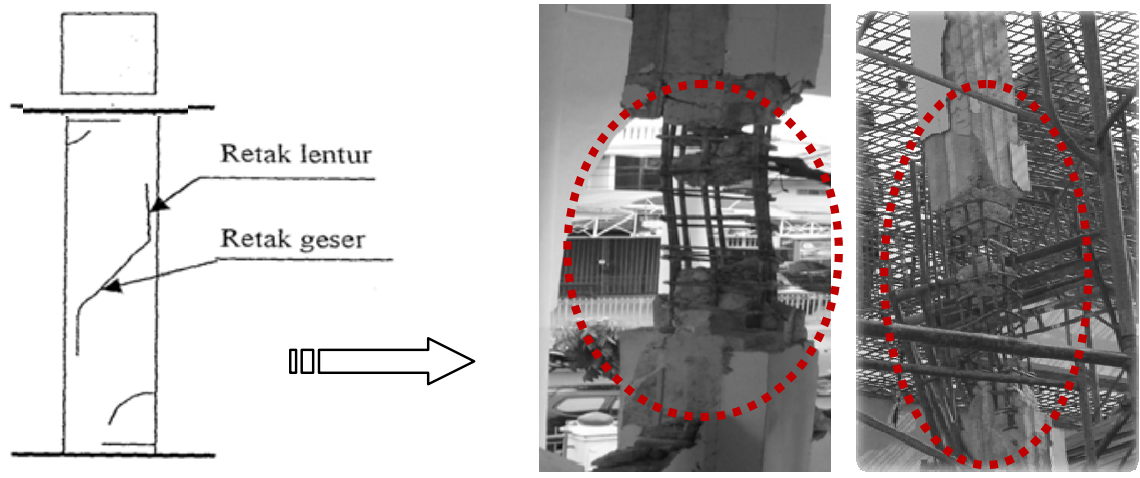

Gambar 3. Bentuk/Pola Retak yang Terjadi pada Kolom Akibat Beban Geser

Kegagalan struktur kolom akibat lentur sangat dipengaruhi oleh kekuatan batang-batang tulangan yang dibebani secara aksial, kekuatan batang-batang tersebut sangat tergantung kepada kekuatan tekan beton. Berdasarkan hasil pengujian mutu beton dilapangan didapatkan mutu beton yang digunakan untuk struktur kolom tergolong rendah yaitu $146,8 \mathrm{~kg} / \mathrm{cm}^{2}$ lebih kecil dari standar yang diharuskan, yaitu $225 \mathrm{~kg} / \mathrm{cm}^{2}$ (Wahyudi dkk, 1999), yang merupakan salah satu penyebab kerusakan lentur pada kolom bangunan Masjid ini. Kegagalan struktur kolom akibat geser terjadi karena aksi gaya-gaya berlawanan arah (beban gempa) yang menyebabkan satu bagian struktur 
bergeser (slip) terhadap bagian didekatnya. Kolom eksisting pada bangunan ini mengalami kegagalan geser yang disebabkan oleh kolom memiliki tulangan geser dengan jarak sengkang yang besar sehingga kolom tidak mampu menahan beban gempa.

\section{PEMODELAN STRUKTUR BANGUNAN}

\subsection{Pemodelan Struktur Eksisting}

Bentuk geometris struktur bangunan kondisi eksisting dengan pemodelan 3 dimensi menggunakan software SAP V 0.9 dan Etabs V.9.0.7. Pada Gambar 4. menunjukan pemodelan struktur kubah pada bangunan masjid raya andalas padang pasca gempa. Struktur kubah dimodelkan dengan spherical dome.

Pada Gambar 5. menunjukan pemodelan struktur beton bertulang pada struktur bangunan Masjid Raya Andalas Padang pasca gempa, dimana komponen struktur yang dimodelkan meliputi struktur kolom, struktur balok dan struktur pelat lantai.
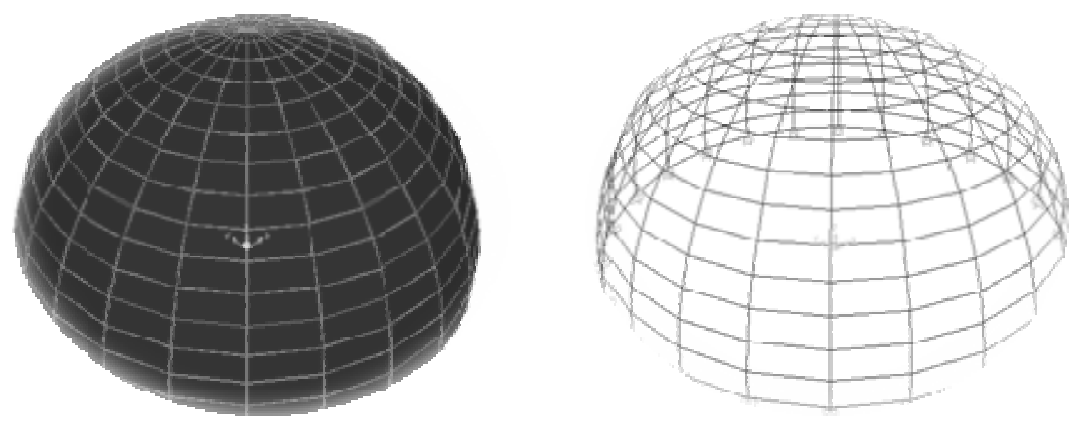

Gambar 4. Pemodelan Kubah Masjid Raya Andalas (Kondisi Eksisting)

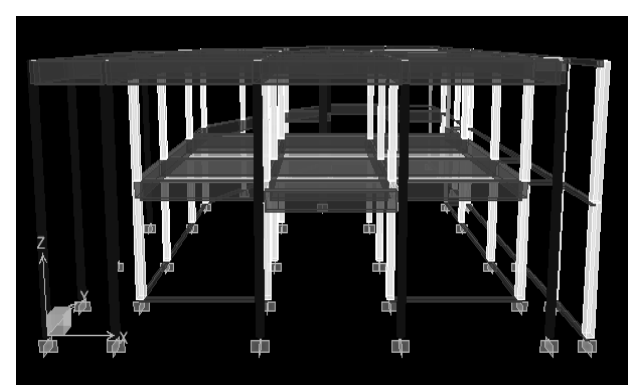

a. Tampak Depan

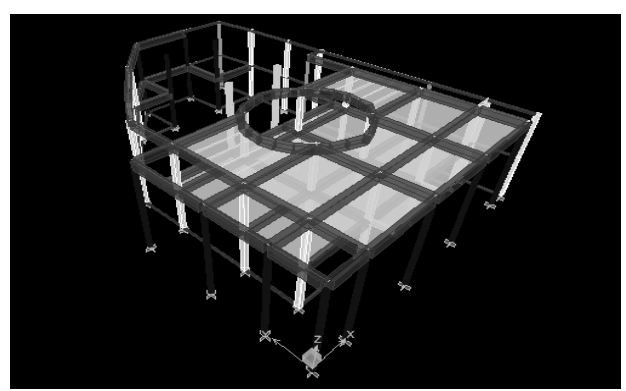

b. Tampak Tiga Dimensi

Gambar 5. Pemodelan Masjid Raya Andalas (Kondisi Eksisting) 


\section{ANALISA STRUKTUR BANGUNAN}

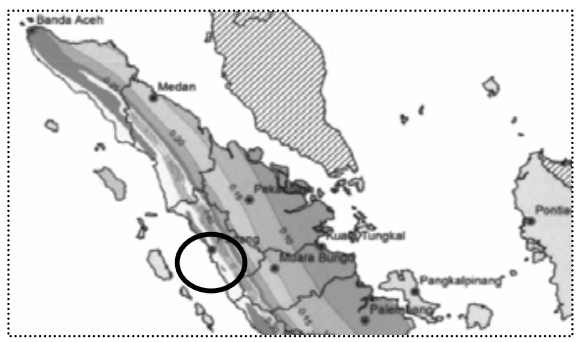

a. Percepatan 1 detik

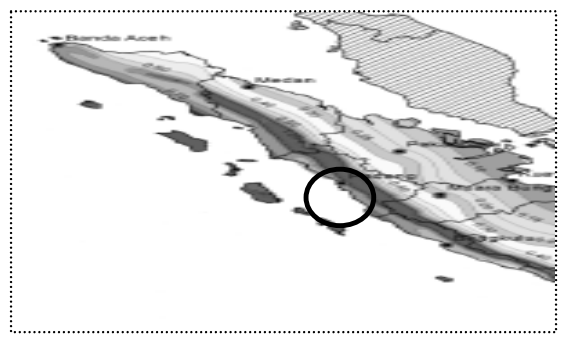

b. Percepatan 0,2 detik

Gambar 6. Peta Hazard Gempa 2010 Wilayah Sumatera (Departemen PU, 2010)

Sesuai data-data diatas, struktur bangunan dianalisis dan disimulasi dengan menggunakan perangkat komputer. Analisa struktur bangunan eksisting dibagi menjadi dua struktur yaitu struktur kubah beton bertulang yang di analisa dengan menggunakan software SAP V 11 dan struktur rangka beton bertulang dianalisa menggunakan software ETABS V 9.0.7. (Andrianto, 2007) Untuk beban horizontal berupa beban gempa (SNI 03-1726-2002) dianalisa menggunakan metoda respon spectrum dengan mengacu pada peta hazard gempa wilayah Indonesia tahun 2010 (Departemen PU, 2010). Pada Gambar 6.a menunjukan peta gempa untuk wilayah kota Padang dengan respon spectra percepatan 1 detik di batuan dasar SB untuk probabilitas terlampaui 10\% dalam 50 tahun (redaman 5\%). Kota Padang memiliki respon spectra = 0,3-0,4g. Pada Gambar 6.b menunjukan peta gempa untuk wilayah kota Padang dengan respon spectra percepatan 0,2 detik di batuan dasar SB untuk probabilitas terlampaui 10\% dalam 50 tahun (redaman 5\%), kota Padang memiliki respon spectra $=0,8-0,9 \mathrm{~g}$.

\section{- Analisis Ragam Respon Spektrum}

Gambar 7a. menunjukan grafik bentuk tipikal respon spectra desain di permukaan tanah dimana bangunan berdiri. Pada Gambar 7b. menunjukan grafik Peak Ground Accelaration (PGA) hasil analisa respon spektrum menggunakan software ETABS V.9.0.7

Dari hasil analisa respon spektrum menghasilkan ragam vibrasi sehingga dapat dilihat pada Tabel 2. bahwa gerak ragam 3 dan 4 bangunan eksisting dominan terhadap rotasi.

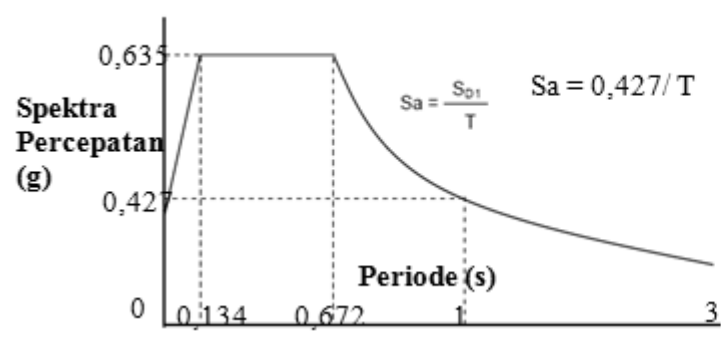

a. Grafik Bentuk Tipikal Respon Spektra Desain Di Permukaan Tanah

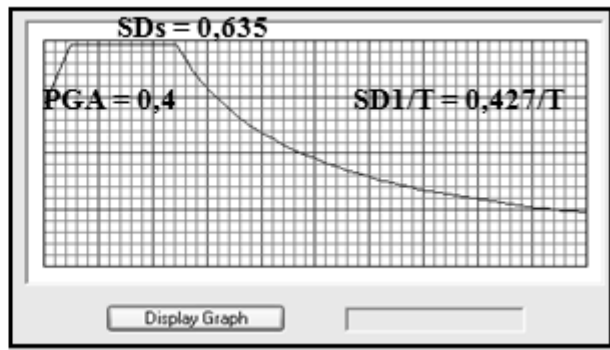

b. Grafik Peak Ground Accelaration Dengan Menggunakan Software Etabs V.9.0.7

Gambar 7. Hasil Analisa Respon Spektrum 
Tabel 2. Modal Participating Mass Ratio Respons Spectrum Struktur Kondisi Eksisting

\begin{tabular}{|c|c|c|c|c|c|}
\hline Mode & Period & $\mathrm{UX}(\mathrm{m})$ & $\mathrm{UY}(\mathrm{m})$ & $\mathrm{RX}\left({ }^{\circ}\right)$ & $\mathrm{RY}\left({ }^{\circ}\right)$ \\
\hline 1 & 6.207848 & 0.0002 & 0.066 & 0.0115 & 0.0003 \\
\hline 2 & 6.07527 & 0.0003 & 0.0673 & 0.0136 & 0.0004 \\
\hline 3 & 4.94408 & 59.8037 & 0.2977 & 0.4099 & 68.6472 \\
\hline 4 & 4.63565 & 0.0489 & 84.548 & 90.2445 & 0.0417 \\
\hline 5 & 4.618761 & 0.3829 & 1.8568 & 1.9622 & 0.6685 \\
\hline 157 & 0.012555 & 0 & 0 & 0 & 0 \\
\hline 160 & 0 & 0 & 0 & 0 & 0 \\
\hline & & 97.6548 & 97.6548 & 97.9279 & 97.9279 \\
\hline
\end{tabular}

Berdasarkan Tabel 2. diketahui bahwa nilai rotasi arah x adalah 90,2445 pada ragam 4 dan rotasi arah y adalah $68,647^{\circ}$ pada ragam 3 menunjukan kondisi dominan dimana bangunan mengalami rotasi karena pada gerak ragam ini terjadi perbedaan respon arah gerak antara lantai 1 dan lantai 2. Untuk gerak ragam selain gerak ragam 3 dan 4 tidak menunjukan adanya pengaruh rotasi pada bangunan dan sudut putarannya sangat kecil yaitu $0^{\circ}$ sampai $1^{\circ}$.

\section{HASIL DAN PEMBAHASAN}

\subsection{Analisa Kapasitas Lentur Penampang Kolom}

Pada Gambar 8. menunjukan denah kolom-kolom eksisting bangunan yang mengalami kegagalan dan kemudian dianalisis penyebab keruntuhan kolom-kolom ini. Berdasarkan analisa struktur didapatkan hasil bahwa sebagian besar keruntuhan kolom beton bertulang dipengaruhi oleh gaya aksial dan momen yang bekerja pada kolom. Ini dapat dilihat pada Gambar 9 - 11.

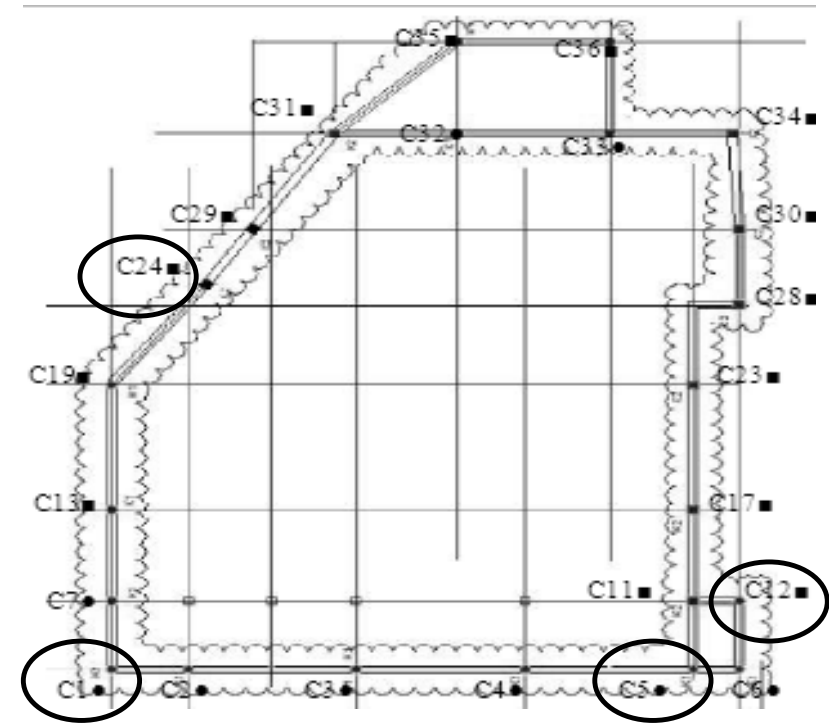

Gambar 8. Denah Kolom-Kolom Ekisisting yang Mengalami Keruntuhan 


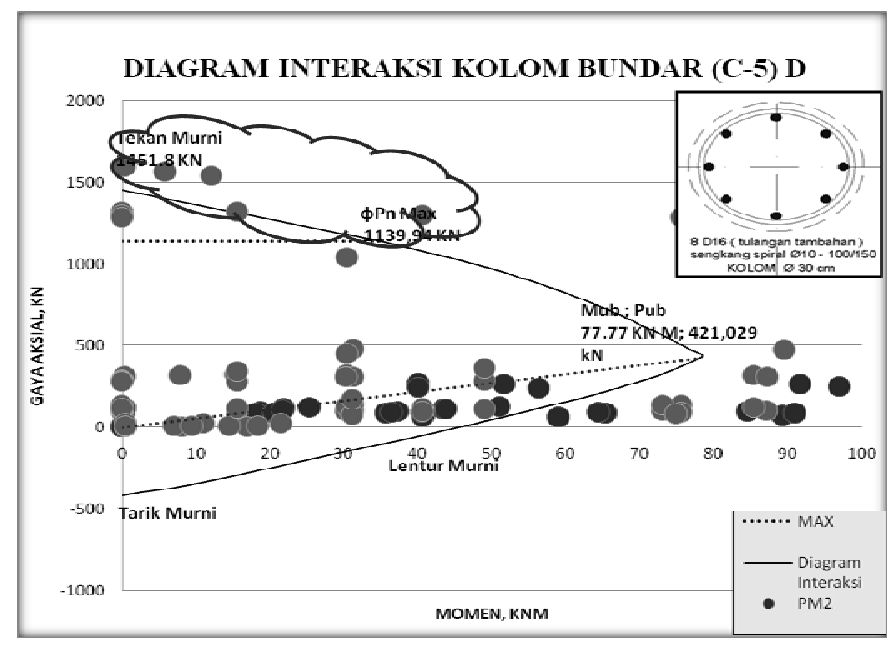

Gambar 9. Grafik Kapasitas Beban Aksial Terhadap Momen pada Kolom C5

Dari diagram interaksi kolom C5 (Gambar 9.) terlihat bahwa nilai beban aksial yang bekerja pada kolom cukup besar dan gaya momen yang bekerja juga besar sehingga melebihi kapasitas penampang kolom. Momen maksimum yang bekerja pada kolom C1 yaitu $100 \mathrm{kNm}$ melebihi kapasitas momen yang mampu diterima kolom sebesar 77,77 kNm sedangkan gaya aksial yang bekerja pada penampang kolom sebesar $1500 \mathrm{kN}$ melebihi kapasitas penampang terhadap gaya aksial sebesar $1461,8 \mathrm{kN}$, sehingga berdasarkan diagram interaksi tersebut kolom ini tidak mampu lagi untuk menahan beban-beban luar yang bekerja.

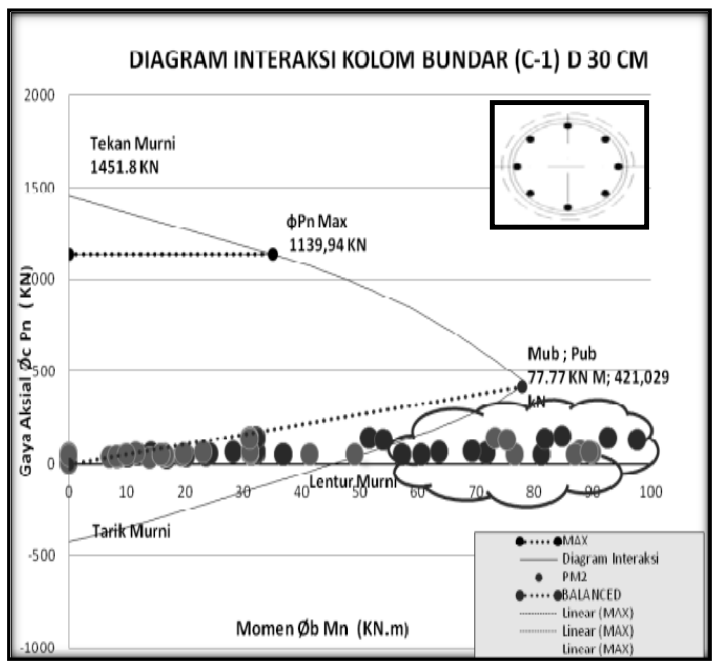

Gambar 10. Grafik Kapasitas Beban Aksial Terhadap Momen Pada Kolom Bundar C1

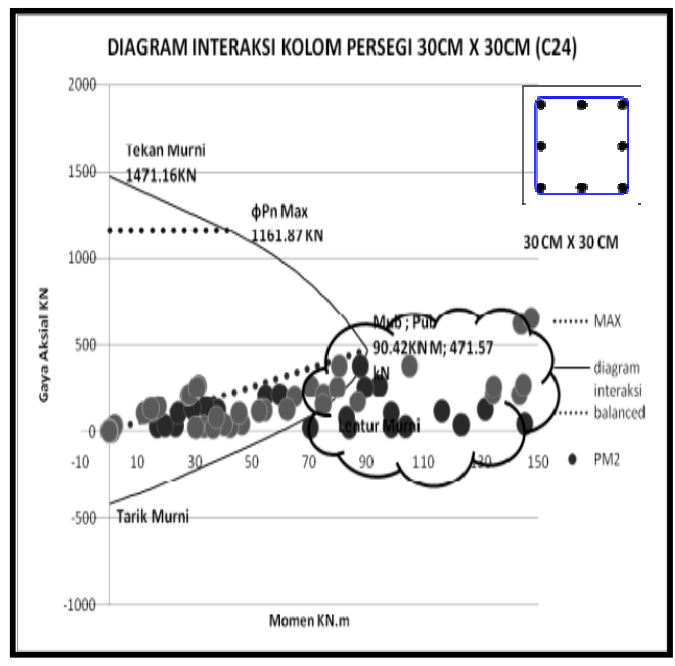

Gambar 11. Grafik Kapasitas Beban Aksial Terhadap Momen Pada Kolom Segi Empat

Dari diagram interaksi kolom $\mathrm{C} 1$ dan $\mathrm{C} 24$ (Gambar 10 - 11.), beban aksial yang bekerja pada penampang kolom kecil sehingga pengaruh beban aksial diabaikan, namun gaya momen yang 
bekerja pada penampang kolom ini melebihi batas kapasitas momen nominal sehingga keruntuhan kolom ini dipengaruhi oleh keruntuhan tarik. Momen maksimum yang bekerja pada kolom $\mathrm{C} 1$ yaitu $100 \mathrm{kNm}$ melebihi kapasitas momen yang diterima kolom sebesar 77,77 kNm sedangkan gaya aksial pada penampang kolom kecil. Momen maksimum yang bekerja pada kolom C24 sebesar $150 \mathrm{kNm}$ melebihi kapasitas momen maksimum yang diterima kolom sebesar 90,42 kNm sedangkan gaya aksial pada penampang kolom C24 kecil. Berdasarkan diagram interaksi tersebut kolom-kolom ini tidak mampu lagi untuk menahan beban yang bekerja.

\subsection{Analisa Kapasitas Geser Kolom}

Kapasitas geser kolom merupakan kemampuan kolom dalam menerima besarnya gaya geser yang bekerja, gaya geser akan besar pada kolom yang melentur. Kolom melentur disebabkan oleh beban lateral yang diterima oleh kolom. Pada bangunan ini beban lateral yang diterima kolom berupa beban gempa, oleh karena itu gaya geser menjadi besar karena dipengaruhi oleh beban gempa. Gambar 12. menunjukan grafik kapasitas geser kolom bundar C32, kolom interior dan kolom eksterior $\mathrm{C} 1$.

Dari Gambar 12. dapat diketahui kapasitas geser untuk kolom interior lebih kecil dari kapasitas geser kolom eksterior $\mathrm{C} 1$, ini ditunjukan dengan tidak adanya titik-titik beban geser didaerah lapangan kolom C32 kolom interior dibandingkan kolom eksterior C1.

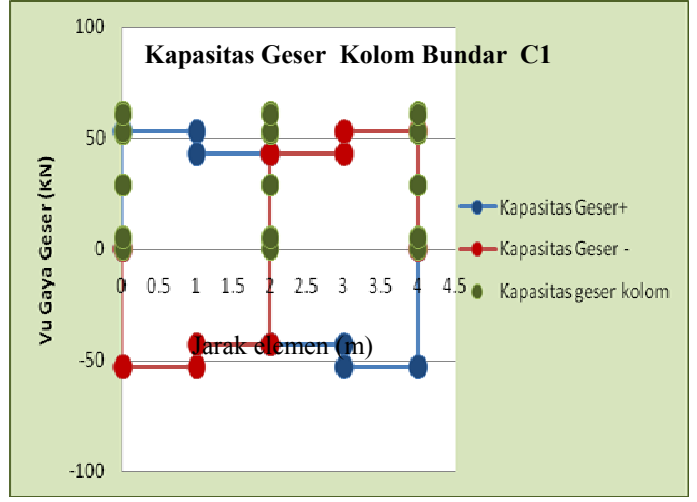

a. Kolom Eksterior

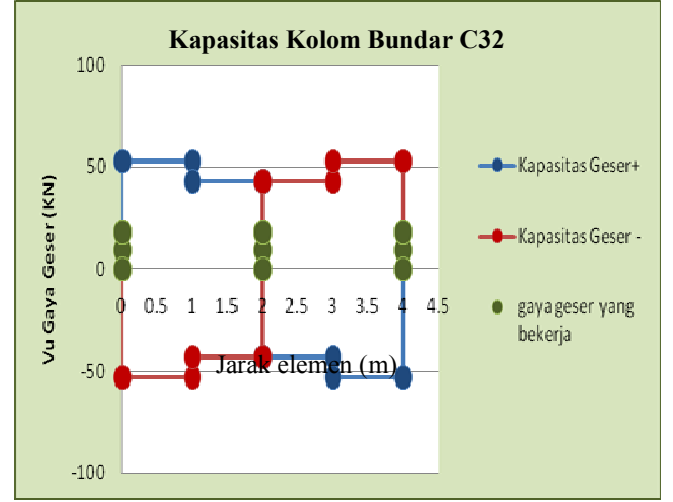

b. Kolom Interior

\section{Gambar 12. Gaya Geser yang Terjadi Pada Kolom Bangunan Masjid Raya Andalas Padang Pasca Gempa}

\section{PERKUATAN STRUKTUR KOLOM (RETROFITTING)}

\subsection{Sistem Retrofitting yang Direkomendasikan Pada Bangunan}

Sistem retrofitting yang direkomendasikan pada bangunan ini adalah metoda jacketing yaitu metoda perkuatan yang dilakukan dengan memperbesar dimensi penampang dan menambah jumlah tulangan (Boen, 2010). Dengan sistem ini kapasitas penampang akan bertambah dalam menahan gaya aksial, momen dan geser yang bekerja. Gambar 13. menunjukkan sketsa sistem jacketing yang direkomendasikan pada kolom-kolom bangunan Masjid Raya Andalas Padang.

Setelah dilakukan re-analisis struktur diketahui bahwa kolom-kolom yang dijacketing sudah mampu menahan beban-beban luar yang bekerja. Ini dapat dilihat pada diagram interaksi 
penampang kolom seperti terlihat pada Gambar 14 dan 15.
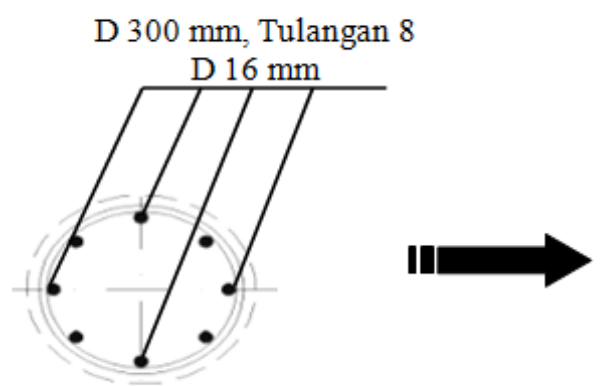

Ukuran $300 \mathrm{~mm} \times 300 \mathrm{~mm}$, Tulangan $8 \mathrm{D} 16 \mathrm{~mm}$
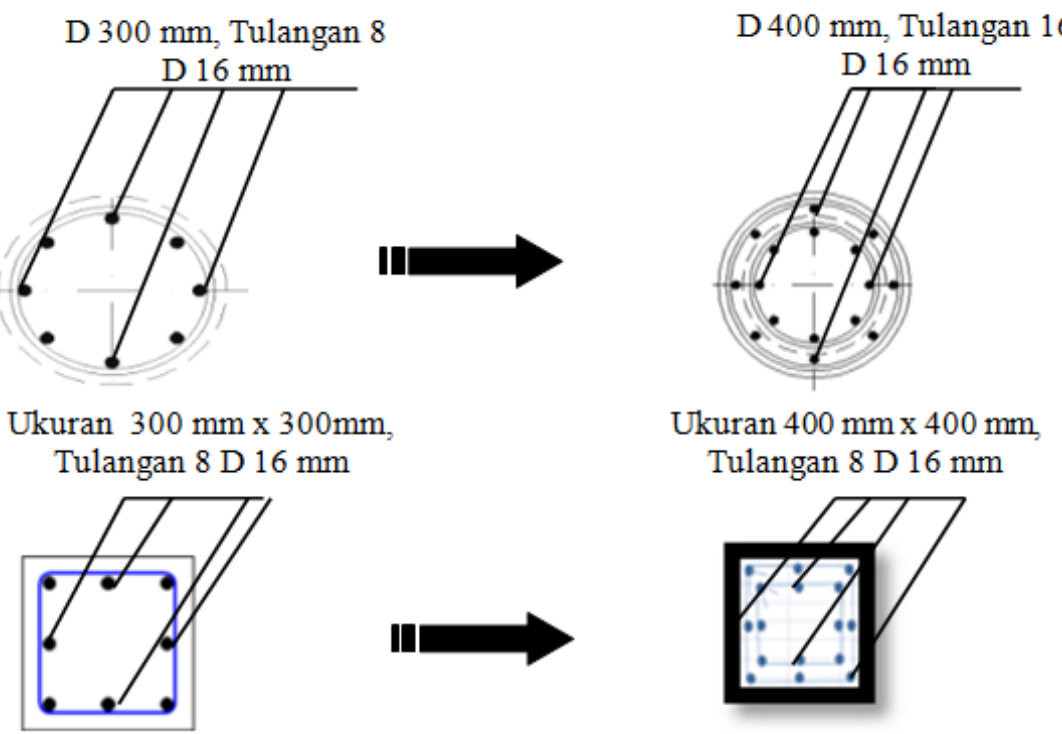

Ukuran $400 \mathrm{~mm}$ x $400 \mathrm{~mm}$, Tulangan 8 D $16 \mathrm{~mm}$
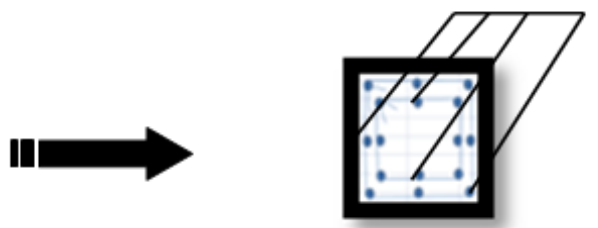

\section{Gambar 13. Sketsa Penambahan Kapasitas Penampang}

Setelah dilakukan jacketing pada kolom eksisting, maka kembali dilakukan pemodelan struktur bangunan setelah retrofitting dengan software analisa struktur Etabs V. 9.0.7. Pada pemodelan ini struktur bangunan dibagi menjadi 2 struktur yaitu struktur 1 merupakan struktur atap rangka baja (stugger truss) dan struktur 2 merupakan struktur gabungan beton betulang dengan atap rangka baja. Pemodelan tiga dimensi Bangunan dapat dilihat pada Gambar 16.

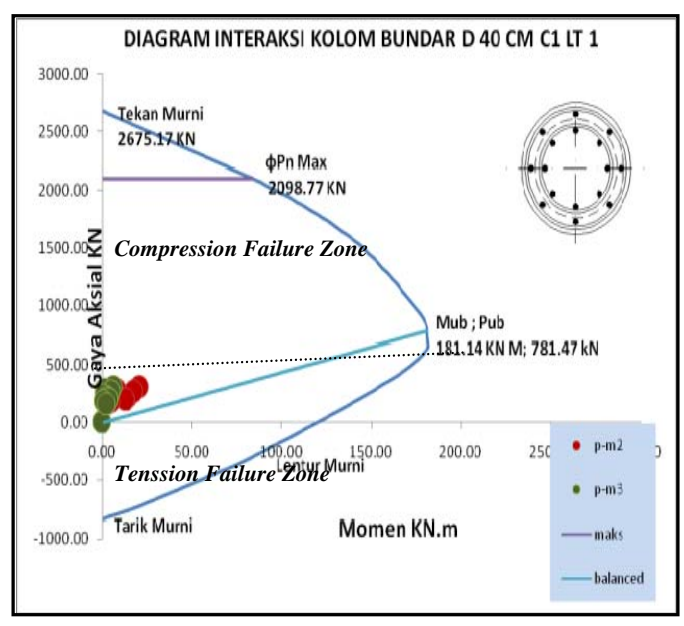

Gambar 14. Diagram Interaksi Penampang Kolom Bundar C1 Sesudah Jacketing

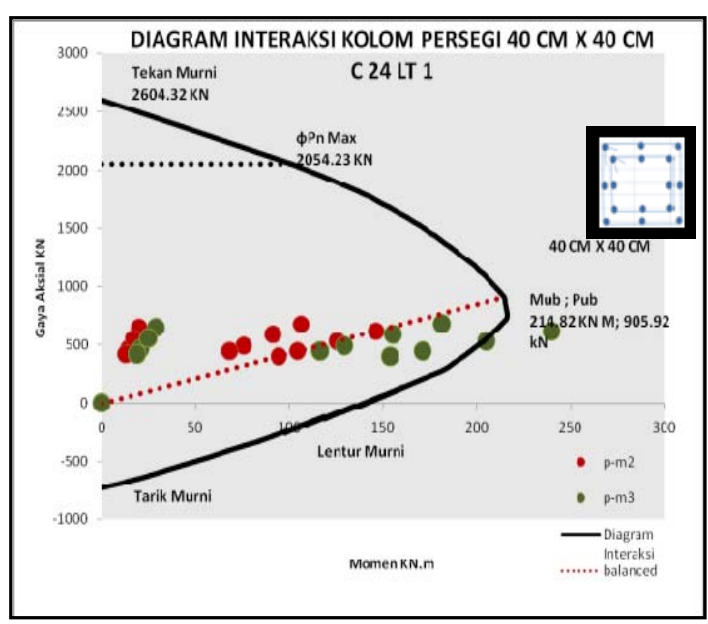

Gambar 15. Diagram Interaksi Kolom Segi Empat C 24 Sesudah Jacketing

Berdasarkan hasil analisa struktur pada kolom bundar $\mathrm{C} 1$ setelah jacketing diketahui bahwa gaya momen dan gaya aksial yang bekerja pada kolom ini sudah dapat ditahan oleh kapasitas penampang kolom dimana terlihat titik-titik momen-aksial sudah berada didalam kurva. Pada 
kolom segiempat C24 setelah jacketing diketahui bahwa gaya momen dan gaya aksial yang bekerja pada kolom ini sudah dapat ditahan oleh kapasitas penampang kolom dimana terlihat sebagian besar titik-titik momen-aksial sudah berada didalam kurva dan hanya sebagian kecil yang diluar.

Berdasarkan hasil analisa struktur pada kolom bundar C1 setelah jacketing diketahui bahwa gaya momen dan gaya aksial yang bekerja pada kolom ini sudah dapat ditahan oleh kapasitas penampang kolom dimana terlihat titik-titik momen-aksial sudah berada didalam kurva. Pada kolom segiempat C24 setelah jacketing diketahui bahwa gaya momen dan gaya aksial yang bekerja pada kolom ini sudah dapat ditahan oleh kapasitas penampang kolom dimana terlihat sebagian besar titik-titik momen-aksial sudah berada didalam kurva dan hanya sebagian kecil yang diluar.

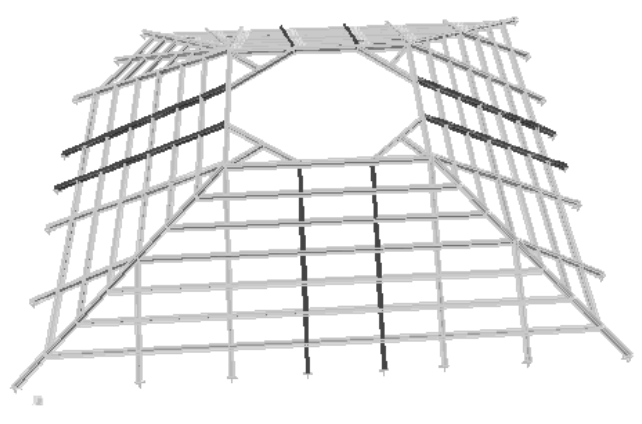

Struktur 1

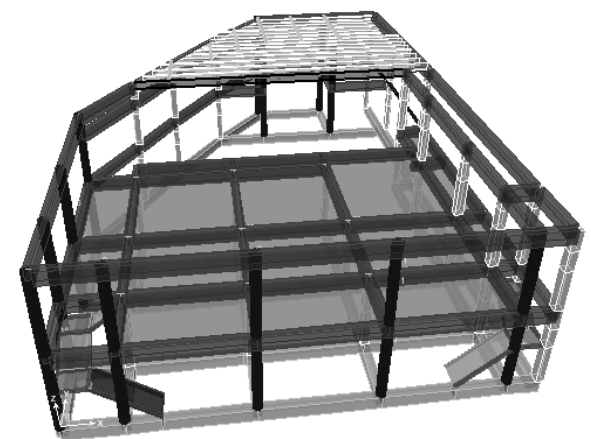

Struktur 2

Gambar 16. Tampak Depan Pemodelan 3D

Grafik kapasitas geser kolom bundar C1 sesudah jacketing pada Gambar 17. menunjukan bahwa gaya geser yang bekerja pada kolom bundar sudah berada dibawah kapasitas geser maksimum. Berdasarkan hasil analisa struktur untuk kapasitas geser kolom sesudah jacketing dimana kuat geser nominal yang disumbangkan oleh beton pada penampang dan tulangan geser setelah nilai kuat geser nominal direduksi mempunyai nilai jauh lebih besar dibandingkan nilai kuat geser ultimate $(\varnothing . \mathrm{Vn} \geq \mathrm{Vu})$.

Gambar 17. merupakan grafik simpangan titik (point) salah satu sumbu kolom akibat gaya lateral/ gempa yang bekerja pada kolom tersebut. Grafik ini menunjukkan perbandingan besarnya simpangan (displacement) sebelum dan sesudah dilakukan retrofitting pada kolom bangunan tersebut. Kedua grafik menunjukan bahwa simpangan sebelum retrofitting lebih besar dari simpangan setelah retrofitting baik dalam arah horizontal maupun vertikal. Dalam arah horizontal pada ketinggian $8 \mathrm{~m}$ displacement mengalami penurunan sebesar $50 \%$ sedangkan dalam arah vertikal displacement mengalami penurunan sebesar 19\% (Gambar 18.).

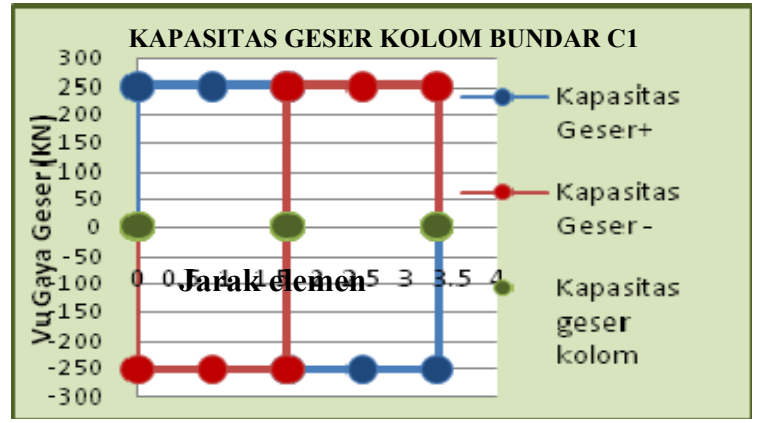

Gambar 17. Grafik Kapasitas Kolom Bundar C 1 Sesudah Jacketing 


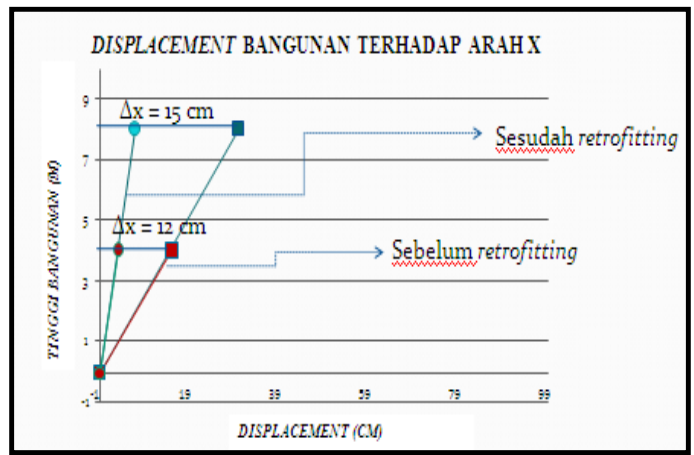

b. Displacement Arah x

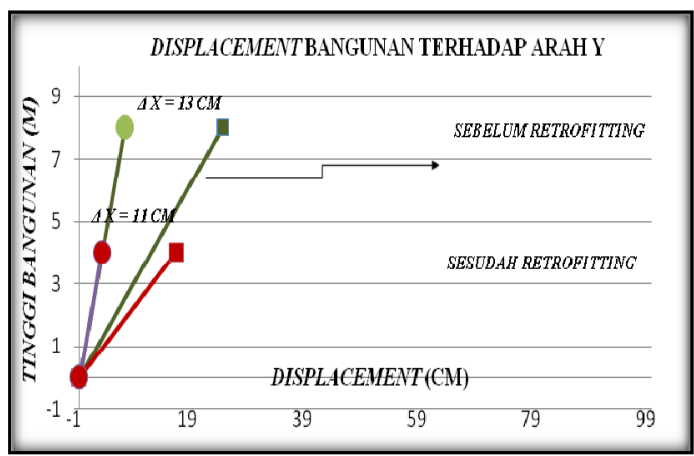

a. Displacement Arah y

Gambar 18. Displacement yang Terjadi Pada Bangunan Kondisi Eksisting dan Setelah Diberi Perkuatan

\subsection{Metoda pelaksanaan Retrofitting Bangunan Masjid Raya Andalas Padang Pasca Gempa} 30 September 2009

Metoda pelaksanaan perkuatan dengan menggunakan jacketing pada salah satu kolom bangunan Masjid Raya Andalas Padang dapat dilihat pada Gambar 19.

a.

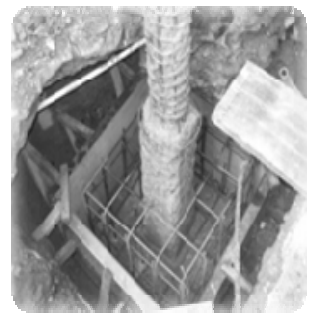

Pemasangan tulangan lentur dan tulangan geser tambahan yang di jacketing

d.

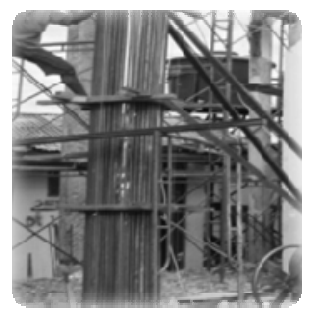

Pemasangan bekisting pada kolom eksisting yang sudah dijacketing

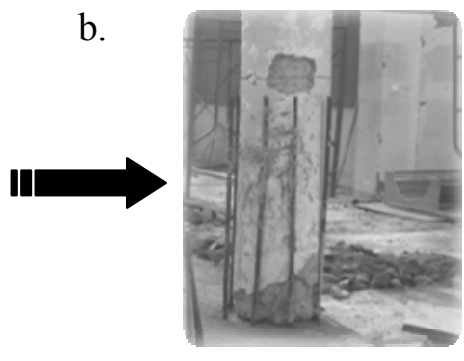

Penambahan kapasitas pondasi poer $1 \mathrm{~m} 2$

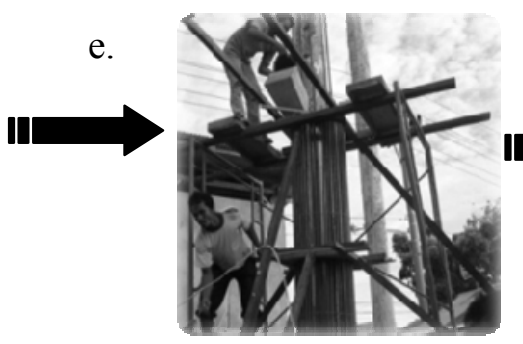

Penambahan kapasitas pondasi poer $1 \mathrm{~m} 2$

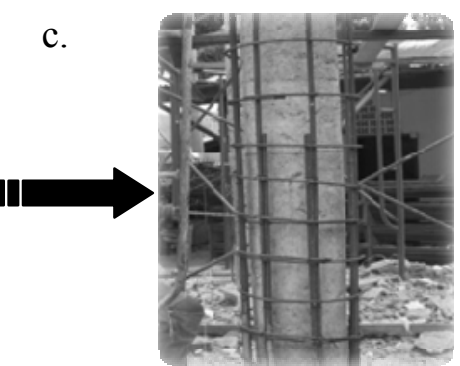

Pemasangan stek tulangan pada poer

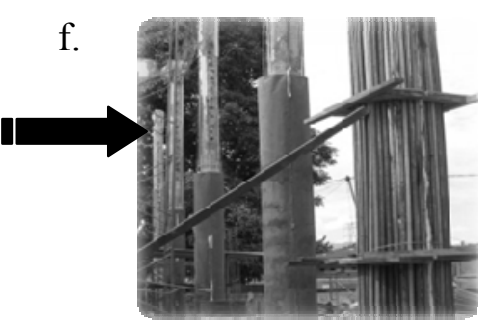

Penambahan kapasitas pondasi poer $1 \mathrm{~m} 2$

Gambar 19. Metoda Pelaksanaan Jacketing 
Dari Gambar 19. dapat dilihat metoda dan proses pelaksanaan jacketing pada kolom. Dimana pertama kali dilakukan pemasangan tulangan lentur dan tulangan geser tambahan yang di jacketing. Setelah itu dilakukan penambahan kapasitas pondasi poer $1 \mathrm{~m}^{2}$ dan pemasangan stek tulangan pada poer. Setelah itu bekisting dipasang pada kolom eksisting yang sudah di jacketing. Langkah terakhir adalah dengan melakukan pengecoran.

\section{KESIMPULAN}

Dari serangkaian penelitian dan analisis yang dilakukan, disimpulkan sebagai berikut:

1. Kolom beton bertulang pada bangunan ini mengalami dua jenis kegagalan yaitu kegagalan aksial lentur dan kegagalan geser.

2. Berdasarkan analisa struktur dan tinjauan lapangan, diketahui beberapa penyebab kegagalan struktur yaitu:

a. Tulangan geser yang terpasang pada kolom, memiliki jarak antara yang besar.

b. Struktur kolom dan balok menggunakan mutu beton yang rendah.

c. Bangunan memiliki bentuk geometri yang tidak beraturan.

3. Untuk menghindari pembebanan atap yang tidak merata pada kolom lantai satu dan dua karena pengaruh dari perbedaan kekakuan kedua lantai akibat tidak simetrisnya lantai satu, dilakukan perkuatan pada atap bangunan dengan mereduksi beban atap pelat beton kondisi eksisting diganti beban rangka atap baja dan penutup atap berupa kubah pelat ringan.

4. Peningkatan kapasitas struktur terhadap gaya-gaya luar yang bekerja pada setelah jacketing adalah sebagai berikut:

Displacement tinggi $8 \mathrm{~m}$ arah $\mathrm{x}$ mengalami penurunan sebesar $50 \%$

Displacement tinggi $8 \mathrm{~m}$ arah y mengalami penurunan sebesar $19 \%$

5. Setelah dilakukan retrofitting pada elemen struktur bangunan, sebagian besar dari elemen struktur sudah dapat menahan beban luar yang bekerja terutama beban gempa sehingga bangunan aman untuk digunakan kembali.

\section{DAFTAR KEPUSTAKAAN}

Andrianto. H.R., (2007), “Analisis Struktur Gedung Dengan Etabs Versi 9.0.7”, Jakarta: PT.Elex Media Computindo.

Boen. Teddy, (2010), "Retrofitting Simple Buildings Damaged By Earhquakes”, United Nations Center For Regional Development (UNCRID).

Depertemen Pekerjaan Umum, (2010), "Buku Panduan Penggunaan Revisi Peta Hazard Gempa Indonesia 2010", Jakarta.

SNI 03-1726-2002, (2002), "Standar Perencanaan Ketahanan Gempa untuk Struktur Bangunan Gedung”, Badan Standarisasi Nasional, Puslitbang Pemukiman, Bandung.

SNI 03-2847-2002, (2002), "Tata cara Perhitungan Struktur Beton untuk Bangunan Gedung”, Badan Standarisasi Nasional, Puslitbang Pemukiman, Bandung.

Wahyudi, L dan Syahrir A. rahim, (1999), "Struktur Beton Bertulang Standar Baru SNI T- 151991-03.00" , Jakarta: PT Gramedia Pusta Utama. 